\title{
A Systems Model to Make, Market, and Lead Your Way towards Sustained Growth
}

\author{
Raman Kumar Agrawalla
}

Tata Consultancy Services Ltd., Bhubaneswar 751024, India; raman.a@tcs.com; Tel.: +91-674-6644-007

Academic Editors: S. Krupanidhi, Leonie Solomons and John J. Kineman

Received: 30 March 2017; Accepted: 26 May 2017; Published: 1 June 2017

\begin{abstract}
Business enterprises exist in a world that is fiercely competitive, tied with huge global uncertainties. They always encounter increasing pressure on prices and margins. Hence, irrespective of their domain of operations and industry, businesses are naturally concerned about their growth, specifically sustained profitable growth, in today's world. Marketing is a key business function to market and lead a business towards sustained profitable growth but the problem is it lacks a systems perspective in its operations, strategy, and practice. Further, given the confluence and systemic interactions of various economic, digital, and competitive forces; the challenge for different business functions-including marketing-increases tremendously. In this context, it is important for business enterprises to have a systems perspective to find their ways to growth that will be sustained. This calls for a holistic approach to assimilate and steer the business functions in any enterprise. The present conceptual paper focuses on an important business function for sustained growth in a holistic way and presents a systems model, called 'Value Based Business Approach (VBBA)-marketing', which has potential to guide and steer companies and business enterprises to create a path for their sustained profitable growth.
\end{abstract}

Keywords: systems model; marketing; value; VBBA; systems perspective; systems thinking; sustained growth

\section{Introduction}

Companies or enterprises, irrespective of their domain of operations and industry, are concerned about their growth, specifically sustained growth. In fact, the concerns for business growth is a global phenomenon now as there are not only shrunken business cycles, but also increasing uncertainties and varied vagaries affecting businesses worldwide. A quick look at the recent trends in the global economy and society clears the global picture that could be seen as a sort of slowdown in the global trade and stagnation in the developed economies. Further, there is increasing penetration of digital forces underlying a 'fourth industrial revolution' and simultaneously showing volatility in financial markets; raising the global issues of migration, protectionism, and turbulence in many parts of the world. In this context, it is important for business enterprises to have a systems perspective to find their ways to growth that will be sustained. This calls for a holistic approach to assimilate and steer the business functions in any enterprise. The present paper focuses on an important business function for sustained growth in a holistic way and presents a systems model towards this end. The rest of the paper is organized as follows:

- $\quad$ After the introduction, we present a brief survey of the literature in Section 2.

- Create a context for our systems model which is presented and discussed in Section 3.

- Section 4 concludes. 


\section{A Brief Review While Setting the Context}

Philip Kotler argues, "Marketing is in bad shape. Not marketing theory, but marketing practice" [1]. Again, it is observed that CEOs are understandably growing impatient with marketing. They feel that they get accountability for their investments in finance, production, IT, even purchasing, but do not know what their marketing spending is achieving. No doubt, marketing as an activity is being practiced since long but as a recognized independent economic discipline it came to fore only in the first decade of the 20th century. As a business philosophy, the 'marketing concept' as emerged in the 1950s, is aimed at orienting a business organization completely towards its customers. Peter Drucker, in 1955 observed that it is increasingly being realized by marketing that "it is our job to produce what the market needs" whereas the traditional attitude towards marketing has been- "the sales department will sell whatever the plant produces" [2]. Further, long ago, Peter Drucker declared that the purpose of a business is to create a customer. The purpose is to provide something for which an independent outsider, who can choose not to buy, is willing to exchange his purchasing power [3]. In fact, it is the customers' willingness to pay which dictates and determines the amount of value or economic profit that the business firm can appropriate and this is primarily a function of the value customers get from the business transaction. McKenna argued in 1986 that traditional product-focused marketing was an anachronism and building relationships was one of the three underpinnings of marketing (namely, 'understand the market', 'move with it', and 'form relationships') [4]. To make the concept of marketing more relevant to the objectives of today's top management, Doyle propounds 'value-based marketing' wherein he argues that "the purpose of marketing is to contribute to maximizing shareholder value and that marketing strategies must be evaluated in terms of how much value they create for investors" [5]. In the present paper, we propound a systems model to marketing that can guide companies to create a path for their sustained growth; which is presented as a 'VBBA to marketing' subsequently in the paper.

\subsection{Minefields a Marketer Wanders into}

Discussing various challenges in 'managing the marketing function', an HBR case studies collection interestingly sees the 4 Ps 'marketing mix' as the "minefields a marketer wanders into" [6]. The 'marketing mix' describes the blend of choice of products, price, promotion, and place that a business organization deploys. Jerome McCarthy in 1960s formulated it as 'the 4 Ps of marketing' namely, product (including all the features like service and packaging, attached to what you sell), place (referring to distribution channels), promotion (all forms of communications with customers), and price (including discounts, pricing flexibility, and so forth) [7]. Of course, in the burgeoning marketing literature, there is a lot of discussions about some other Ps such as people, process, pace and so on, applicable specifically to 'services marketing'. It is argued that the marketers' job is to research new opportunities for the company and carefully apply segmentation, targeting, and positioning (STP) to take the business in the desired direction. It is thus marketer's job to ensure that the marketing mix is coherent in the sense that the 4 Ps are consistent with each other and the STP strategy. Again, in the evolution of marketing, one finds in the literature a sort of shift from managing marketing mix to adopting what is called 'strategic marketing'. True that targeting essentially means carefully selecting your customers having better Customer Life Cycle value (CLV), who are thus really profitable for the business organization. Thus, these high CLV customers, if served appropriately and harnessed in a win-win way, can be instrumental in the journey of sustained growth of business enterprises. Here the choice of markets and market segments and the way offerings are positioned, matter most. This way, a marketing plan and strategy is drawn which needs to be implemented flawlessly with intermittent monitoring or implementing through what Deming says "plan, do, check and act" [8].

\subsection{Marketing Challenges: Now and the Future}

We live in a time when businesses face huge global uncertainty, increasing pressure on prices and margins; and the market scene, both local and global, is fiercely competitive. The challenges 
for marketing are increasing day by day. We attempt to discuss briefly the challenges both from the technology and business sides and the implications for business in general and marketing in particular. Table 1 schematically describes various bases for the modern marketing challenges and the business implications for the marketer in coming days. In fact, these challenges are already being experienced by the marketers since the emergence of the new information economy or the digital and the network economy. As can be seen from Table 1, the modern marketing challenges perpetuate thanks to different ways of working of the network and digital economy, as explained below.

Table 1. Challenges for the marketing in the changing context.

\begin{tabular}{|c|c|c|}
\hline $\begin{array}{l}\text { Basis of Changing } \\
\text { Marketing Context }\end{array}$ & Traditional Marketing Paradigm & Modern Marketing Challenges \\
\hline $\begin{array}{l}\text { Pace and change in } \\
\text { business/market }\end{array}$ & Slow and linear & Fast and non-linear \\
\hline Concern & Stability & Change management \\
\hline Perspective & Silo & Systems \\
\hline Value outlook & To self or to customer & Positive value to all \\
\hline Business identity & What you sell & How and who you sell \\
\hline Product/technology life cycle & Long & Short \\
\hline Competition & Size matters, local & Speed matters (fast eats slow), global \\
\hline Customer force/pressure & Functional & Aspirational \\
\hline Business space & Physical & Cyber, digital \\
\hline Sale, marketing, branding & $\begin{array}{l}\text { How best to target potential } \\
\text { customers? }\end{array}$ & $\begin{array}{l}\text { How best to be targeted by potential } \\
\text { customers? }\end{array}$ \\
\hline Assets & Tangibles & Intangibles \\
\hline Drive & Push & Pull \\
\hline Activities & Material processing & Knowledge processing \\
\hline Socio-economic scene & Orderly & Chaotic \\
\hline
\end{tabular}

\subsection{Information Rules in the Network Digital Economy and Marketing Implications}

According to Shapiro and Varian, there are four 'information rules' [9], the rules of a network economy, which help understand the behavior of the information or digital economy. The four 'information rules' are:

1. Technology changes. Economic laws do not.

2. Information is anything in digital format that people are willing to pay for.

3. Information is costly to produce but cheap to reproduce.

4. The information economy is driven by the economics of networks.

Information is described as anything that can be digitized-encoded as a stream of bits. Books, databases, cricket scores, magazines, movies, music, stock quotes, internet-based advertising, and web pages are all termed as 'information goods'. These can also be called 'experience goods'. Because, customers must first use and experience these goods to evaluate their benefits and value. Hence, consumers differ greatly in how they value particular information goods. Again, some information goods may have entertainment value for some or business value and accordingly their willingness to pay differs. This has a bearing on the strategies that suppliers of information goods adopt. It is currently a common knowledge that electronic commerce increases the viability of using the extreme form of differential pricing, wherein the company can personalize the offering and personalize the price on an individual basis for some information goods, using dynamic pricing software and agent-based technologies, as seen in the airlines industry.

\subsection{Five 'New Forces', Porter's Five Forces, and Five Digital Forces Changing the Rules of Competition}

In the information age and the network digital economy, we experience change in some of the basic rules of competition. In fact, there are five new forces that have been shaping competition in the new information or network or digital economy. These five new forces are ascribed to Metcalfe's 
law ('the utility or the value of the network equals the square of the number of users'), Moore's law (speed of microprocessors doubles every 18-24 months), Transaction Cost Economics (attributed to Ronald Coase, the noble laureate in economics for his seminal contribution in this area), the flock of birds phenomenon, and the fish-tank phenomenon (that ensures access to all, and facilitates minimum entry barriers) [10]. In fact, though the importance of Porter's five forces to competitive strategy is still sacrosanct and marketers have to cope with them, the five new forces that have come to the fore, (because of the 'death of distance' and the digital revolution) require the marketer to keep pace and need to relook at his marketing mechanisms, instruments and arsenals, in the light of the consequent changing competitive and business dynamics in the market place. Porter's five forces include the threat of substitutes, the threat of new market entrants, internal rivalry among the competitive players, the bargaining power of suppliers, and the bargaining power of customers. In fact, the first three forces relate to 'horizontal' competition whereas the latter two forces are from 'vertical' competition [11]. These forces are in fact pertaining to firm's micro-environments. For marketers, the macro environment is equally important to planning, deciding, and executing its strategies in a constantly changing environment. Hence, the effective marketers adapt their marketing programs to various dimensions of changing macroeconomic environments. The larger holistic macroeconomic business environment is provided by the SPECTACLES framework, which is the acronym for (Social, Political, Economic, Cultural, Technological, Aesthetic, Customers, Legal, Environmental, and Sectoral) [12]. I have an opinion that some factors may have immediate/short term consequences, and some other medium and long-term consequences. Hence, marketing through SPECTACLES should be tuned and toned accordingly when marketers adapt their marketing programs to the various dimensions of the holistic global environment.

Coupled with these five new forces and Porter's five forces, the new digital five forces (SMAC-social, mobility, analytics, cloud computing and big data, AI, pervasive computing, and cognitive technologies) represent the new digital and the ICT-dominated network economy for the marketing and marketers and other business players and economic agents. These factors do arise when companies, people, and computers are tied together in huge digital networks and in a situation of everything being connected with everything else. Because of the new challenges and humongous change in technological and digital facilities for information and communications, we thus see the big and varied changes that the business of marketing are undergoing, seen through the economics of networks and the consequent information rules and digital re-imagination of enterprises and businesses.

Again, marketers are facing aspirational and activist customers who are more informed and sophisticated in their buying habits, increasing the modern marketing challenges. Furthermore, mass marketing costs are rising even though mass marketing effectiveness is falling. Digital marketing seems to be of hope, to some extent. With the increasing focus on innovation by all the companies, it is becoming difficult for firms to maintain differentiation to enjoy sustainable competitive advantage. Thus, the challenges for the marketers are only going to increase further in the future, both in variety and intensity. The implication of these modern marketing challenges gives rise to a situation wherein the marketers find it a herculean task to preserve company margins and achieve company profit targets. According to Kotler (2006), "many companies are inefficiently organized from a marketing point of view and that makes the matter much worse. Adding company marketing inefficiency and ineffectiveness to all these business challenges is a recipe for disaster" [1]. For all these challenges, we present our systems model—VBBA Marketing— to create sustained and profitable growth for businesses.

\section{A Systems Model to Make and Market Your Way to Growth}

In our systems model, called the VBBA Marketing, the Value Based Business Approach (VBBA) is all about having a systems perspective, following a holistic value-oriented management process and getting guided and governed by a positive sum value creation outlook [13]. The VBBA presents a triad in terms of a Positive Sum Value Creation Outlook, Value Creating System, and Value-Based 
Management (see Figure 1), which enables the business firm to land on the virtuous value spiral helping client or customer business to land on its own virtuous value spiral.

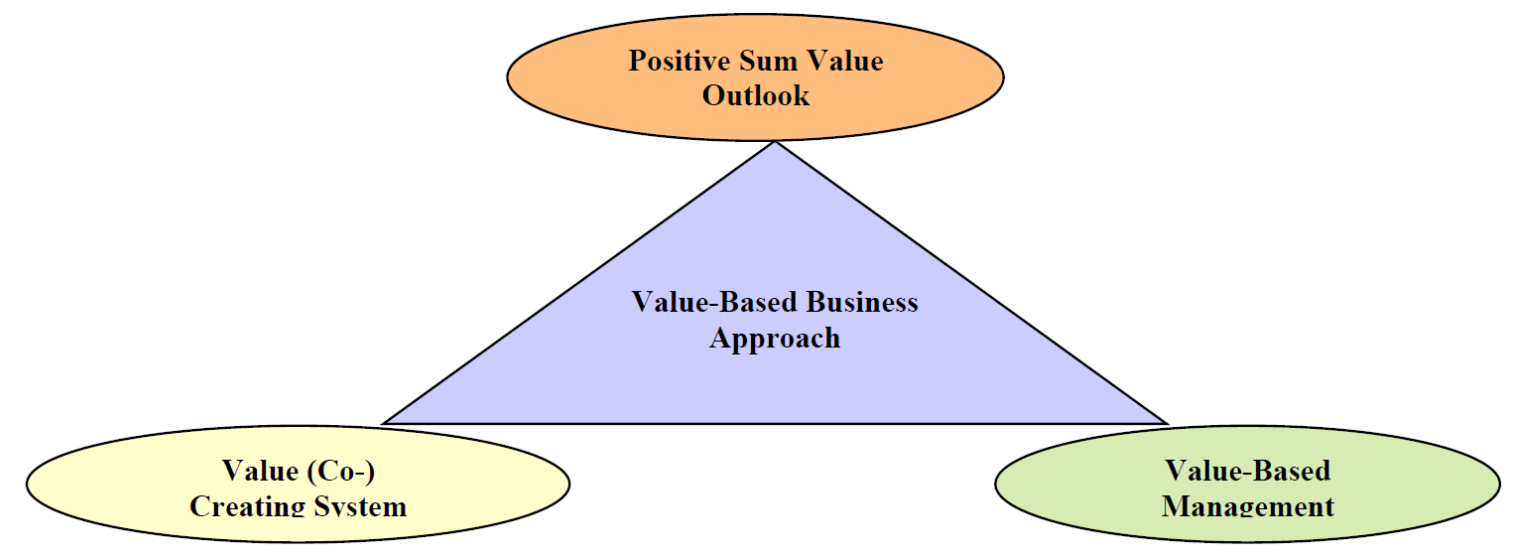

Figure 1. Value-Based Business Triad. Source: Agrawalla, 2009, Journal of Systemics, Cybernetics, and Informatics. Volume 7-Number 5.

The purpose of business is to create value for its customers helping them create value for themselves and to assure and ensure happiness of all involved in the value creating system. In other words, the purpose is to survive and thrive in a fluctuating, ever-changing environment, to make money with ever increasing net cash-inflows, and to ensure positive value to all the stakeholders. It is instructive to point out that in the VBBA, business enterprises are also steered by some larger purpose that goes much beyond mere money-making. It is evident from its emphasis on the idea of 'positive value to all the stakeholders', including society.

While talking of marketing for sustained growth, the idea is for businesses to have increase in sales revenue and profit providing a win-win deal to all the stakeholders in the value co-creating system. In other words, businesses, embracing values based management and a positive sum value creation approach, can ensure not only a win-win-win situation for all concerned in the value creating system-namely customers and counterparts, shareholders, suppliers, partners, associates/employees, community, and the society at large — but can also successfully land on a virtuous value spiral ensuring business-success-and-sustainability. Further, it is argued that in the modern digital networked economy, value engine, and knowledge engine are in a positive feedback loop, one driving the other, in a virtuous cycle towards the path of exponential growth and prosperity for businesses [14]. When the business enterprise attains such a state, it is said to be on a path of 'sustained growth'. Control is in-built in our systems model through the imposition of certain benign constraints. That is, while pursuing sustained profitable growth, the VBBA aims at first 'to expand the value universe' and simultaneously ensure value and its sustainability for all concerned in the value creating system commanding certain constraints, namely "benefits to customers exceed their total cost of ownership, return on investment to shareholders exceed the opportunity cost of their capital, compensations to employees exceed their transfer earnings besides providing them ample avenues for self- and career development and finally society benefits in terms of, among other things, increase in positive externalities and reduction in negative spillovers" [14].

Naturally, a business will pass through various stages of maturity in its life cycle. However, businesses with the VBBA are supposed to operate the value creating system with agility, speed, economy, and innovation $[13,14]$ and hence can attempt to jump its ' $S$ ' curve beating the growth cycle in time.

While emphasizing on sustained growth, it is argued that no business can afford to neglect the 'value to society' for long. In the VBBA, businesses can care for societal value and the needs for its sustainability catering to varying needs and wants of the society and its people and 
posterity, providing them more choices, better experiences, and opportunities creating, co-creating, and co-innovating economic goods (including 'green' goods) and making them available, accessible, affordable, and enjoyable to the customers. All in all, businesses will provide value to society if they can operate the value creating system in such a way that it is job creating, poverty reducing, participatory, culturally enshrined, and environmentally friendly [14].

With the above discussion, we propound our systems model, the VBBA to marketing in terms of the Figure 2.

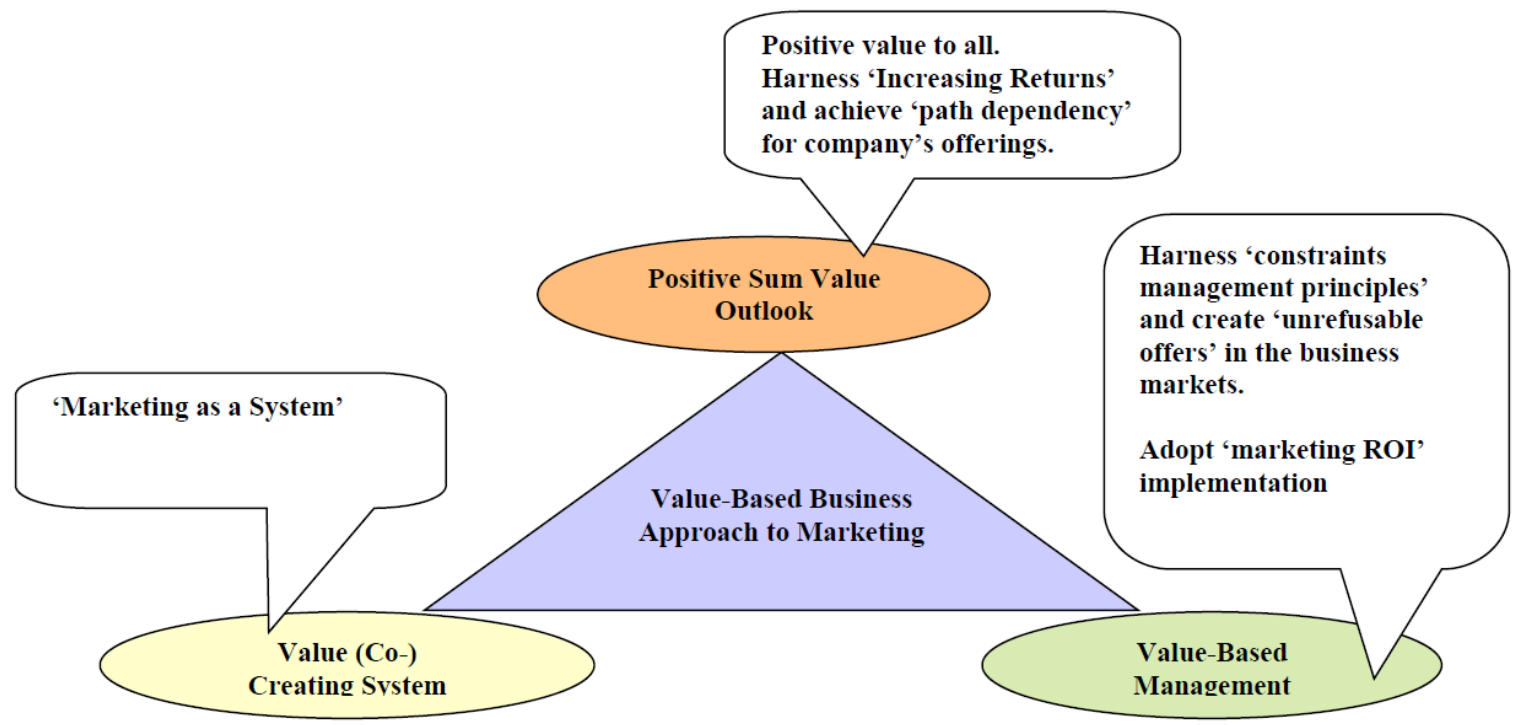

Figure 2. A systems model to create your path to sustained growth.

\subsection{Marketing as a Value Co-Creating System}

The proposed systems model of VBBA-marketing requires marketers to see 'marketing as a system'. Here, it is instructive to dwell a little on the idea of system for the general readers. "A system can be defined as a set of elements standing in interrelations" [15]. A system is an integrated whole, it is a perceived whole [16]. Having a systems perspective entails studying the system as a whole in the context of its environment and the larger business eco-system employing a non-reductionist approach. It is the pattern of interactions among the systemic elements and their relationship to each other, and to the whole that renders better understanding of the system in focus; that is, in the present context, marketing as a value co-creating system (see Figure 2). It is obvious to state that the holistic business efforts to create a marketer's offer happens in a co-creation mode.

Further, it is worth clarifying the term 'value' in our systems model wherein marketing is seen as a value co-creating system. Because, value may mean different things to different people and it may be differently interpreted in different disciplines, indicating many faces of value. Sometimes people express their understanding of value in some philosophical or meta-physical terms. Many times, it is used to denote importance. However, value is most often confused with cost or price. The term value is being extensively used in disciplines, such as Economics, Strategy and Strategic Management, Marketing, Accounting and Finance, System Sciences, Psychology, and Sociology of consumer behaviors and the likes.

In the present context, value is defined as net benefits accruing to customers (and to any other stakeholder in the value co-creating system) in money terms. It also includes all the non-monetizable benefits and the intangibles. In particular, value to customer is seen as a set of net-benefits and it rides on and/or through offering of business to customers. That is, value to customer is created through business offerings and processes, products and their qualities, services surrounding the business and so on. For the purpose of analysis, value to customers in the consumer markets can be seen as satisfaction 
to the consumers and the end-users and their delight, and in the business markets as improvement in the sales revenue and profit of the customer business.

Interactions and relationships with customers is one of the important dimensions of value. Value to customers may arise from one or more of an offering's attributes. It may also arise at one or more points of interaction between customer enterprise and business enterprise. Information Technology, internet, and all the new forces of digital technologies have been playing a significant role in this regard. Thanks to the increased access to information, networking, and consumer activism, consumers in the modern economy are more active, informed and connected. Stressing co-creation of value with customers, Prahalad and Ramaswamy (2004) observe that "Companies can no longer act autonomously, designing products, developing production processes, crafting marketing messages, and controlling sales channels with little or no interference from consumers. Consumers now seek to exercise their influence in every part of the business system. Armed with new tools and dissatisfied with available choices, consumers want to interact with firms and thereby co-create value. The use of interaction as a basis for co-creation is at the crux of our emerging reality" [17]. The illustrations of the value co-creation in the VBBA-marketing systems model can be seen and explained invoking von Foersterian second-order cybernetics, seeing business enterprise and its customers' enterprise as entities observing and observed by each other $[14,16]$.

When we emphasize 'seeing marketing as a system', it is apt to quote Drucker as this idea of marketing being connected to all areas of business system is reflected in his treatise on 'the practice of management'. To quote Drucker [2] (p. 36), "It (marketing) encompasses the entire business. It is the whole business seen from the point of view of its final results, that is, from the customer's point of view. Concern and responsibility for marketing must therefore permeate all areas of the enterprise". From his field studies of marketing practice, Drucker elaborates that "thus marketing, through its studies and research, will establish for the engineer, the designer and the manufacturing man what the customer wants in a given product, what price he is willing to pay, and where and when it will be wanted. Marketing would have authority in product planning, production scheduling and inventory control, as well as in the sales distribution and servicing of the product". Thus, the marketing should be involved in the whole chain of activities from conception of ideas leading to production of goods and services up to the point when money flows into the business system. However, Drucker's systemic idea of is still not being fully practiced by marketing, so much so that Kotler laments that "most of marketing is reduced to a one-P function-Promotion-not a four-P job" [1] (p. 3). As the company ends up making a product that does not sell well, most of marketing's task is to clear up the mess through hard selling and advertising. Describing the 10 most common, and most damaging-mistakes marketers make, Philip Kotler suggests solutions for marketers, which are: marketers to learn how to stay market-focused and customer-driven, fully understand their customers, keep track of the competition, manage relationships with stakeholders, find new opportunities, develop effective marketing plans, strengthen product and service policies, build brands, get organized, and use technology to the fullest. In a recent book, Kotler and Kotler (2013) described eight general and known ways to growth possibilities for businesses for marketing [18].

\subsection{Marketing with a Positive Sum Value Outlook}

By a positive sum value outlook, we mean business to be considered and conducted as a non-zero positive sum affair. That is, all involved in the business, which is a value co-creating system with its dharma as value creation, should be assured of positive value always. It of course assumes that all involved in the value creating system are contributing their bit enthusiastically towards the expansion of the value universe [14], that is, to increase the net total value addition by their respective outcome-oriented activities.

Thus, considering marketing as a value co-creating system, the marketing strategy, plans, and processes should be formulated to provide value to all, and the marketers should be able to harness 'path dependency' in the sense that it creates 'lock-in' for customers for company goods and 
services, so that the business lands on the virtuous value spiral. In this way, the 'switching costs' for customers can increase preventing them or dis-incentivizing them from switching-over to competing offerings or solutions. The more successful the marketers are at getting customers more locked-in to their products and business solutions, the more successful they will be in keeping customers at peak prices, increasing the money flowing into their business system. For this, the suggested strategies could be, "invest to build an installed base, cultivate influential buyers and buyers with high switching costs, get your customers to invest in your technology, thereby raising their own switching costs, sell complementary products and access to your installed base" [9]. In fact, this way the marketers can harness 'increasing returns' and achieve 'lock-in' and 'path dependency' for a company's products, offerings, and business solutions. Path dependency refers to the tendency for first movers in the market to establish leads that are virtually impossible for late starters to catch up on. This phenomenon is also described as 'sensitivity to initial conditions' in chaos theory.

It is known that companies operating in the network economy often experience increasing returns specifically for the economic activities involving high technologies. This is because the value of technology-product to new users depends on the total numbers of other users using the same product. As the base of users grows, more and more users join, expanding the user community. This perpetuates as a positive feedback loop in the network economy and the companies that get propelled forward by such positive feedbacks become the biggest winners. Shapiro and Varian (1999) discussed four generic strategies in network markets for igniting positive feedback, controlled migration (Windows 98), performance play (Iomega Zip), open migration (fax machines), and discontinuity (records to CDs) [9].

Thus, if marketers can initiate minor initial events in the development of a market that can lead to massive chain effects and feedback loops with very significant effects at a later stage creating 'lock-ins' for their products, offerings, and business solutions, they can capture the market perpetually. In fact, there are numerous stories about cases of path dependency in the new economy, where companies have used superior marketing techniques to gain lasting leads over companies with superior technologies. As software people say, "it is the marketing gods that make the software kings. Software kings build on path dependency" [19].

The champion of increasing returns, Brian Arthur, quotes technology thinker George Gilder, "the central event of the twentieth century is the overthrow of matter. In technology, economics, and the politics of nations, wealth in the form of physical resources is steadily declining in value and significance. The powers of mind are everywhere ascendant over the brute force of things" [20]. Brian Arthur continues to observe that "as the economy shifts steadily away from the brute force of things into the powers of mind, from resource-based bulk processing into knowledge-based design and reproduction, so it is shifting from a base of diminishing-returns to one of increasing-returns. A new economics-one very different from that in the textbooks-now applies, and nowhere is this more true than in high technology. Success will strongly favor those who understand this new way of thinking". Thus, Brian Arthur (1996) rightly observes that Marshall's world, the world of diminishing returns, "is characterized by planning, control, and hierarchy. It is a world of materials, of processing, of optimization. The increasing returns world is characterized by observation, positioning, flattened organizations, missions, teams, and cunning. It is a world of psychology, of cognition, of adaptation". It is based on the processing of resources and on the processing of knowledge. This thus holds a lot of significance for today's agents of business and management, including marketers.

In fact, how the business can ensure a positive value to all stakeholders, which is very important for having a leading edge to lead the sustainable wealth creation and profitable growth and the overall sustainability of the business. Hence, through the systems model to make, market, and lead your way towards sustained growth, the concerns of all the stakeholders are tackled, which enhances and strengthens the ability of the business organization to be on a virtuous value spiral. 


\subsection{Value-Based Management in VBBA-Marketing}

The other important element of our systems model presented here is the idea and element of value-based management. This, in fact, entails the whole gamut of management processes in the business organization to be value-oriented and focused. In fact, value-based management instils a mindset, where everyone in the organization learns to prioritize decisions based on their understanding of how those decisions contribute to corporate value [21]. This in our VBBA-marketing means that all key processes and systems in a corporate or business firm must be oriented not only to the creation of value; but also its credible communication, delivery, and appropriation, benefiting all involved in the value creating system.

Hence, the whole idea is how marketing can help create and capture value for the business, increasing the throughput, increasingly helping the business delivering value to the customers, and demonstrating the value received by the customers. In fact, the typical constraints that the company faces in this regard are its ability to understand the benefits, customers' value, and its ability to communicate these benefits without generating resistance by customers. Our systems model is potential enough to help achieve marketing effectiveness helping managers to create the most compelling offer, including the business solutions and offerings that get co-created in a value co-creation set up that will strengthen the sales process. In general, service providers divide their sales process in the following stages [22]:

- Identification: Client has a problem it cannot solve on its own.

- Validation: Service provider can solve the client's problem.

- Qualification: Services have sufficient value to the client and profit for the provider.

- Proposal: Services can be delivered in a manner acceptable to the client.

- Contracting: Client and provider agree on responsibilities, terms, and conditions.

- Delivery: Service provider and client implement the services and exercise change control.

As we understand, at different stages of marketer-client interactions, there could be various resistances to the marketer's offers (see Table 2) and our systems model has ways and means to help the managers to effectively overcome the obstacles and resistances, especially in business markets.

Table 2. 'Layers of resistance' from client encountered by the marketer.

\begin{tabular}{c}
\hline 'Layers of Resistance' from Client Encountered by the Marketer \\
I do not have that problem. \\
My problem is different. \\
The problem is not under my control. \\
I have a different direction for a solution. \\
The solution does not address the whole problem. \\
The solution has negative outcomes. \\
There are obstacles to implementing the solution. \\
I am not clear how to implement the solution. \\
Now we have to change what we are used to.
\end{tabular}

This idea of 'layers of resistance' is attributed to Eliyahu Goldratt's theory of constraints thinking processes [23] in which the author has deep expertise and practical experience. Salespersons will get resistance when they move to next layer without taking care of previous ones in Table 2 . It is important to note that not all the layers of resistance exist or are very important to all customers, but a salesperson has to make sure there are no obstacles or resistances in the client's mind for the business solution or offerings. A client must convincingly see the benefits and value that they will derive, so that their business results would improve. Note that, as underlined earlier in Section 3.1, creation of a marketer's offer occurs in a value co-creation mode, particularly involving the client and other relevant stakeholders, such as the partners, suppliers and the likes, as the case may be. 
Applying the 'cybernetics of simplification' model [16], it can be shown that how, based on sufficiency logic, a full proof or sure-fire offer can be created, so that the client sees business value in the marketer's offer and buys the offering, increasing the throughput of the marketer's business (see Figure 3). It is emphasized that efforts are made to overcome the layers of resistance while co-creating the offering, which is particularly relevant in a business-to-business set up.

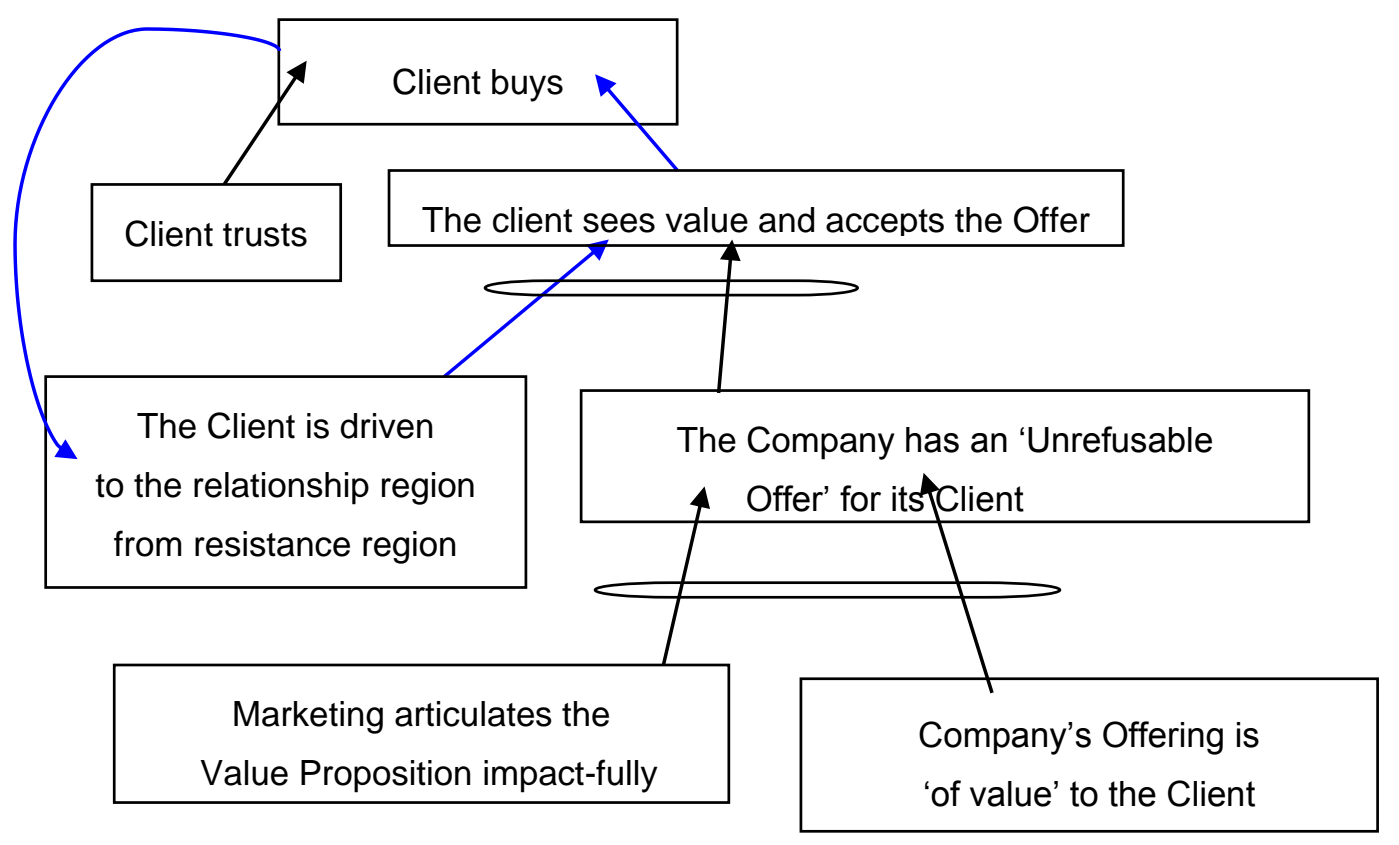

Figure 3. Systems model to create marketer's offer.

In the Figure 3, it can be read from the bottom of the figure that if the company's offering is 'of value' to the client and the marketing articulates the value proposition impact-fully, then the company has an 'unrefusable offer' for its client. This obviously takes place in a value co-creation mode, as discussed in Section 3.1. Further, if the company has an 'unrefusable offer' for its client and the client is driven to the relationship region from resistance region, then the client sees value and accepts the offer. This step provides an additional strength to the business enterprise in earning loyalty of the customer and earn more of its CLV. Furthermore, if the client sees value and accepts the offer, the client buys. This aspect is very important because mere 'co-creation' as in the start may not suffice, unless there is an eventual 'buy-in' by the client and this idea that is implicit in our systems model goes a long way to sustain the business-client relationship, earning CLV and customer loyalty. In fact, in this simple self-explanatory Figure 3, we can see a positive feedback or reinforcing loop (a kind of what I call a 'virtuous value spiral') emerging, because if a client buys then the client is driven to the relationship region from resistance region, strengthening the relationship and securing future business in a sense. In fact, the client is driven to relationship region by the marketer when he employs the systems model of VBBA-marketing, which also helps to remove the layers of resistance from client encountered by the marketer. 'Iteration' is in-built in the 'cybernetics of simplification' model [16] that is employed to create and co-create the marketer's offer. Note that Figure 3 can be expanded both at the bottom and at the top adding many other entities described as effects or causes. Efforts have been made to keep the exposition simple in Figure 3. For instance, it is additionally shown that if the 'client trusts', then the 'client buys' and this can itself be expanded in to a large figure and further links and loops can be seen and established with other relevant entities in the figure. Thus, the systems model of VBBA-marketing has potential to ensure that while dealing with the client and the customers, any sort of resistance to a marketer's offering or business solutions can be removed, 
increasing the throughput of the business system and the enterprise. This way, through our systems model, marketing can increase the throughput of the business organization.

Thus, through our systems model of VBBA-marketing, the marketer can demonstrate convincingly to the client that it is marketer's company's products or services offering or business solutions that can address the client's (or prospect's) needs and the client can derive benefits and value by using the seller's product or services offering. Here, I would like to draw your attention to three laws of marketing physics—namely, overt benefit, a reason to believe, and dramatic difference [24]. Hence, the focus is to know and understand the real current needs of customers. Also, their unarticulated, pre-emergent or even emergent needs. Also, what will they pay for towards the satisfaction of their needs and to their delight? Achievement of client's or customer's satisfaction and delight is essential as it facilitates client's willingness-to-pay which in turn holds the key for the survival and sustainability of the business enterprise. In present-day economies, clients or customers are really the scarcest resources. The higher the number of profitable clients and customers a business earns, the higher its chances to survive and thrive and earn sustained growth.

\section{Conclusions}

The upshot is that the needs of the client are paramount and whatever a business offers, it should meet clients' varied needs, and it should solve clients' problems. In fact, the strong foundations for building world class companies entail the business getting closer to clients and customers and meeting their varied and varying needs consistently, providing positive value to all involved in the value creating system. The quicker and better businesses learn it and apply it practice genuinely, the stronger they emerge as world-class businesses. The role of marketing in this context is important and it can be successfully shouldered if the marketing group sees itself also as a system and our proposed systems model can marshal the efforts-as described in the paper-to make, market, and lead the path towards sustained business growth, increasing the throughput of company profitably.

Acknowledgments: I would like to thank M.G.P.L. Narayana and K. Ananth Krishnan for their help and encouragement. I also take this opportunity to express my gratitude to K.V. Nori, P.N. Murthy, Padma Bhushan S. Ramadorai and Padma Bhushan F.C. Kohli, the pioneers in systems and cybernetics research in my organization, TCS. I am thankful to all of them for being my source of learning and inspiration. I also thank three anonymous reviewers, the editors, and the academic editor for their helpful comments to enrich the paper.

Conflicts of Interest: The author declares no conflict of interest.

\section{References}

1. Kotler, P. Ten Deadly Marketing Sins: Signs and Solutions; John Wiley \& Sons: Hoboken, NJ, USA, 2006.

2. Drucker, P. The Practice of Management; Butterworth-Heinemann: Oxford, UK, 1955; p. 36.

3. Drucker, P. Managing for Results; Butterworth-Heinemann: Oxford, UK, 1964; p. 85.

4. Mckenna, R. The Regis Touch; Addition-Wesley: Reading, MA, USA, 1986.

5. Doyle, P. Value-Based Marketing: Marketing Strategies for Corporate Growth and Shareholder Value; Wiley: New York, NY, USA, 2003.

6. Harvard Business Review Case Studies. Marketing through Minefields; Harvard Business School Publishing Co.: Brighton, MA, USA, 2008.

7. Jerome, M.E. Basic Marketing: A Managerial Approach; Richard D. Irwin, Inc.: Homewood, IL, USA, 1960.

8. Deming, W.E. The New Economics for Industry, Government, Education, 2nd ed.; MIT Press: Cambridge, MA, USA, 1993.

9. Shapiro, C.; Varian, H.R. Information Rules: A Strategic Guide to the Network Economy; Harvard Business Press: Boston, MA, USA, 1999.

10. Capon, N.; Hulbert, J.M. Marketing Management in the 21st Century; Prentice Hall: Upper Saddle River, NJ, USA, 2001.

11. Porter, M. Competitive Strategy: Techniques for Analysing Industries and Competitors; Free Press: New York, NY, USA, 1980.

12. Cartwright, R. Mastering the Business Environment; Palgrave Macmillan: Basingstoke, UK, 2001. 
13. Agrawalla, R.K. A Value-Based Business Approach to Product Line Software Engineering. J. Syst. Cybern. Inf. 2009, 7, 32-37.

14. Agrawalla, R.K.; Nori, K.V. A Cybernetic Value Creation Model of Businesses in the Modern Economy. In Proceedings of the South East Asian Regional Computer Federation SEARCC, Colombo, Sri Lanka, 8-10 September 2006.

15. Von Bertalanffy, L. General System Theory: Foundations, Development, Applications, Revised ed.; George Braziller Press: New York, NY, USA, 1968.

16. Agrawalla, R.K. When Newton meets Heinz Von Foerster, Complexity vanishes and Simplicity reveals. Kybernetes 2015, 44, 1193-1206. [CrossRef]

17. Prahalad, C.K.; Ramaswamy, V. Co-creating unique value with customers. Strategy Leadersh. 2004, 32, 4-9. [CrossRef]

18. Philip, K.; Kotler, M. Market. Your Way to Growth: 8 Ways to Win; John Wiley \& Sons: Hoboken, NJ, USA, 2013.

19. Tvede, L.; Ohnemus, P. Marketing Strategies for the New Economy; Wiley: New York, NY, USA, 2001.

20. Arthur, W.B. Increasing Returns and the New World of Business. Harv. Bus. Rev. 1996, 74, 100-109. [PubMed]

21. Knight, J.L. Value-Based Management; McGraw Hill: New York, NY, USA, 1998.

22. Ricketts, J.A. Reaching the Goal: How Managers Improve a Services Business Using Goldratt's Theory of Constraints; Pearson Plc, IBM Press: Indianapolis, IN, USA, 2008.

23. Goldratt, E.M. It's Not Luck; North River Press: Great Barrington, MA, USA, 1994.

24. Hall, D. Jumpstart Your Business Brain: The Scientific Way to Make More Money; Clerisy Press: Cincinnati, $\mathrm{OH}$, USA, 2005.

(C) 2017 by the author. Licensee MDPI, Basel, Switzerland. This article is an open access article distributed under the terms and conditions of the Creative Commons Attribution (CC BY) license (http:/ / creativecommons.org/licenses/by/4.0/). 